\title{
Morphologic transformation of human breast epithelial cells MCF-10A: dependence on an oxidative microenvironment and estrogen/ epidermal growth factor receptors
}

Rita Yusuf ${ }^{1}$, Krystyna Frenkel ${ }^{2 *}$

\begin{abstract}
Background: MCF-10A, immortalized but non-transformed human breast epithelial cells, are widely used in research examining carcinogenesis. The studies presented here were initiated with the observation that MCF-10A cells left in continuous culture for prolonged periods without re-feeding were prone to the development of transformed foci. We hypothesized that the depletion of labile culture components led to the onset of processes culminating in the observed cell transformation. The purpose of this study was to define the factors which promoted transformation of this cell line.

Results: Changes in levels of phenol red (PHR), hydrocortisone (HC), and epidermal growth factor (EGF) with or without estrogen treatment indicated that both oxidative stress- and estrogen receptor alpha (ER $\alpha$ )-mediated pathways contribute to cell transformation. Gene array and Western blotting analyses of cells maintained in our laboratory and of those from other sources documented detectable ER $\alpha$ and ERbeta (ER $\beta$ ) in this ERo-negative cataloged cell line. Results also indicate the possibility of a direct association of EGF receptor (EGFR) and ER $\alpha$ in these cells as well as the formation and high induction of a novel ternary complex that includes ER $\beta$ (ER $\alpha / E R \beta$ / EGFR) in cells grown under conditions facilitating transformation.

Conclusions: Our studies resulted in the development of a growth protocol where the effects of chronic, physiologically relevant alterations in the microenvironment on cellular transformation were examined. From our results, we were able to propose a model of transformation within the MCF-10A cell line in which oxidative stress, ER and EGFR play essential roles. Overall, our work indicates that the immediate microenvironment of cells exerts powerful growth cues which ultimately determine their transformation potential.
\end{abstract}

\section{Background}

Breast cancer is one of the most common malignancies affecting women in Western countries [1]. Despite extensive research efforts worldwide at understanding and eradicating breast cancer, the cellular processes that lead to the onset of mammary carcinogenesis have yet to be definitively elucidated. Oxidative stress has come under increasing scrutiny in recent years as a causative factor in mammary carcinogenesis. Chronic infection and inflammation, which lead to reactive oxygen species

\footnotetext{
* Correspondence: Krystyna.Frenkel@nyumc.org

${ }^{2}$ Department of Environmental Medicine, NYU School of Medicine, PHL

Room 802, 550 First Avenue, New York, NY 10016, USA

Full list of author information is available at the end of the article
}

(ROS) generation, are recognized risk factors for cancer development [2]. 17 $\beta$-Estradiol (E2) [3-6] and epidermal growth factor (EGF) $[7,8]$, two agents that can increase intracellular oxidative stress, are also strongly linked to the development of breast cancer. E2 binding to estrogen receptor (ER) [9-11] and EGF's known properties as a growth factor, $[1,12]$ as well as its putative role in modulating ER expression [13,14], could also lead to cell transformation through the induction of cellular proliferative responses.

Epidemiological evidence and the recognized risk factors implicate estrogens as important etiological agents in the development of breast cancer [9,15-20]. The exact mechanism(s) by which estrogen contributes to the 
development of breast cancer has not yet been elucidated. Most studies to date have focused on estrogen's role as a promoter of carcinogenesis based on its proven mitogenic activity in cells $[9,10,21]$. Receptor-based increases in cell proliferation due to estrogen binding are thought to act by either increasing spontaneous errors that make target tissues more susceptible to initiation or enhancing the replication of clones of already initiated target cells [10]. Increasingly, however, the notion that estrogen can function as an initiator of breast cancer via ROS generation and consequent oxidative DNA damage is gaining experimental support [3-5,21-24].

Over two decades ago, J. Liehr and coworkers elegantly demonstrated that while $17 \beta$-estradiol (E2) exposure induces renal clear-cell carcinoma in Syrian hamsters, 2-fluoroestradiol (2-Fl-E2), a fluorinated estrogen analog that is a potent estrogen but displays reduced metabolic conversion to catechol estrogen metabolites, was non-carcinogenic in this system $[25,26]$. Oxidation of cytochrome P450-catalyzed catechol estrogen (CE) metabolites, particularly 4-hydroxyestradiol (4-OH-E2), to semiquinones and quinones and their redox cycling, is thought to generate free radicals which can effect oxidative DNA damage $[22,23,27,28]$ leading to mutations and carcinogenesis. 4-OH-E2 is the predominant catechol formed in human mammary fibroadenomas and adenocarcinomas tested [29]. The localized occurrence of a specific estrogen 4-hydroxylase (CYP1B1) in human breast cancer cells, uterine myoma, and rodent target organs of estrogen-induced carcinogenesis has also been observed [29]. Further, formation of 8-hydroxy-2'-deoxyguanosin (8-OHdG) was higher in ER $\alpha$-positive cultured human breast cancer cells and tissues in comparison to ER $\alpha$-negative cells [30]. Studies conducted with human sperm and lymphocytes provided evidence that exposure to various estrogenic compounds can lead to free radical-mediated damage as well. This damage was diminished in nearly all cases by catalase, indicating that estrogen-mediated effects act via hydrogen peroxide $\left(\mathrm{H}_{2} \mathrm{O}_{2}\right)$ production [31].

ER $\alpha$ levels can be modulated by EGF $[13,14]$, which was shown to increase oxidative DNA damage in mammary tumor cells coincident with increased malignancy [7]. EGF, a growth factor regulating the proliferation and differentiation of human mammary epithelial cells, is thought to be involved in the pathophysiology of breast cancer $[1,12]$. Underscoring its significance in mammary carcinogenesis, EGF is present in several human breast cancer cell lines and in $15-30 \%$ of human primary invasive breast carcinomas; its mRNA is elevated in $E R \alpha$-positive human breast cancer cell lines and tumors, and its expression correlates with poor prognosis in breast cancer patients [1]. EGF by itself can increase $\mathrm{H}_{2} \mathrm{O}_{2}$ levels $[7,8]$ and, thus, may be a critical factor in oxidative stress-induced breast cancer.

The culture medium of MCF-10A cells is usually supplemented with various factors such as hydrocortisone (HC), EGF, and phenol red (PHR, a $\mathrm{pH}$ indicator), which can affect redox state as well as ER activity. We observed in this study that MCF-10A cells left in continuous culture for prolonged periods without re-feeding were prone to the development of morphologically transformed foci. Our hypothesis was that the depletion of labile culture components induced oxidative stress and led to the onset of spontaneous transformation. However, deliberate manipulation of culture components and treatment with redox active and inactive estrogens indicated both oxidative stress- and ER $\alpha$ mediated pathways to be operative in the spontaneous transformation of these cells. While MCF-10A cells are characterized as ER $\alpha$-negative, gene array and western blotting analyses of cells maintained in our laboratory as well as of those obtained from a variety of different sources provided documentation of detectable ER $\alpha$ and ERbeta (ER $\beta)$ in this cell line. Western blotting analysis also indicated for the first time the possibility of a direct association of epidermal growth factor receptor (EGFR) and ER $\alpha$ in the MCF-10A cell line as well as the formation and high induction of a novel ternary complex that includes ER $\beta$ (ER $\alpha / E R \beta / E G F R)$ in MCF-10A cells grown under conditions facilitating their transformation.

\section{Materials and methods}

\section{A. Cells and Materials}

MCF-10A cells were purchased from American Type Culture Collection (ATCC; Manassas, VA). MCF-10A cells were also kindly provided by Drs. J.D. Yager (Department of Environmental Health Science, The Johns Hopkins University Bloomberg School of Public Health, Baltimore, MD; Source \#1), K. Eckert (Gittlen Cancer Research Institute, Penn State College of Medicine, Hershey, PA; Source \#2), M. Planas-Silva (Department of Pharmacology, Penn State College of Medicine, Hershey, PA; Source \#3), and M. F. Verderame (Department of Medicine, Penn State College of Medicine, Hershey, PA; Source \#4). The laboratories at Penn State University that kindly provided MCF-10A cells had obtained these cells independently of one another from different sources. A custom formulation of PHR-free Dulbecco's Modified Eagle's Medium/Nutrient F12 (DMEM/F12) cell culture medium D231SA, trypsin $(0.25 \%, 1 \times)$, trypsin-ethylenediaminetetraacetic acid (trypsin-EDTA; $0.05 \%$ trypsin, $0.53 \mathrm{mM}$ EDTA, $1 \times$ ), L-glutamine $(200 \mathrm{mM}, 100 \times)$, and antibiotic/antimycotic $(100 \times)$ solutions were purchased from Atlanta Biologicals (Norcross, GA). Horse serum (HS) was purchased from Invitrogen (Carlsbad, CA). EGF was purchased 
from R\&D Systems (Minneapolis, MN). Protease inhibitor cocktail tablets were obtained from Roche Molecular Biochemicals (Indianapolis, IN). All other reagents were purchased as described in the text or from Sigma Chemical Company (St. Louis, MO).

\section{B. Cell Culture}

MCF-10A cells were maintained in PHR-free DMEM/ F12 culture medium unless otherwise specified. Medium was supplemented with $\mathrm{NaHCO}_{3}(1200 \mathrm{mg} / \mathrm{L}), \mathrm{CaCl}_{2}$ $(1.05 \mathrm{mM}), 5 \% \mathrm{HS}$, insulin $(10 \mu \mathrm{g} / \mathrm{ml})$, L-glutamine (2 $\mathrm{mM})$, antibiotic/antimycotic mixture (1\%), EGF $(20 \mathrm{ng} / \mathrm{ml}), \mathrm{HC}(500 \mathrm{ng} / \mathrm{ml})$, and cholera toxin $(100 \mathrm{ng} /$ $\mathrm{ml})$. Cells were fed twice a week and grown to confluence before subculturing. Briefly, cells were washed once with Dulbecco's Phosphate Buffered Saline (D-PBS) and exposed to trypsin for 15-20 minutes before the action of trypsin was stopped with $20 \%$ HSsupplemented medium. Cells were then centrifuged at $100 \times g$ in a tabletop centrifuge for $5 \mathrm{~min}$ and the cell pellet was resuspended in medium and transferred to other flasks. All cells were grown in a single chamber water-jacketed humidified incubator and maintained in a $37^{\circ} \mathrm{C}, 5 \%$ carbon dioxide $\left(\mathrm{CO}_{2}\right)$ atmosphere. The number of passages cells have been propagated in a particular type of medium is indicated in parentheses next to the description of the medium [(i.e. -HC/-EGF (\#10)]

\section{Assay for Morphologic Transformation}

MCF-10A cells maintained in PHR-free 5\% HS-supplemented, $\mathrm{HC}$ and EGF-containing [+HC/+EGF $(+/+)]$ DMEM/F12 medium were subsequently grown for the 5-week morphologic transformation assay in $+/+,-\mathrm{HC} /-$ EGF (-/-), -HC/+EGF (-/+), or +HC/-EGF (+/-) DMEM/ F12 media supplemented with $0.5 \% \mathrm{HS}$ and $240 \mu \mathrm{g}$ bovine serum albumin (BSA)/ml in the absence or presence of PHR. Cells in these eight medium groups were non-treated (NT) or treated with $0.01 \%$ ethanol (EtOH) alone or with $0.01 \% \mathrm{EtOH}$ solution of $1 \mathrm{nM} \mathrm{E} 2$ or $1 \mathrm{nM}$ 2-fluorestradiol (2-Fl-E2). Initially, cells were either left untreated or treated with appropriate agents and then plated in triplicate in 6-well plates at a density of $5 \times$ $10^{5}$ cells/well. Thereafter, cells were maintained in continuous culture for 6 weeks, refed and re-treated once a week, and examined microscopically each week for signs of contact-uninhibited growth and the appearance of morphologically transformed foci. Transformed foci were counted once a week from 1-5 weeks at $4 \times$ magnification as they appeared along two perpendicular lines intersecting in the center of each well. To assess the reversibility of phenotypic cell alterations, after five weeks, PHR, HC, and EGF were added back singly or together, to cultures that were lacking these factors, and the number of transformed foci was again determined at week 6 . The assay was performed once with duplicates of each treatment analyzed. Some treated cells were plated in poly-D-lysine-coated tissue-culture plates in an attempt to increase detailed microscopic visualization and examination of foci.

\section{Western Immunoblotting Analysis}

Cells used for Western blot analysis included MCF-10A cells (non-treated and treated under various treatment protocols and media conditions) as well as MCF-10A cells acquired from different laboratories and grown in -PHR, 5\% HS, +/+ medium. Total cell extracts were obtained by first trypsinizing and pelleting cells as described in section B of Materials and Methods and washing once with D-PBS. Cell lysis buffer $[5.0 \mathrm{M}$ EDTA, $150 \mathrm{mM} \mathrm{NaCl}, 50 \mathrm{mM}$ Tris $\mathrm{HCl}, 1 \%$ Triton X100, 1\% SDS, $50 \mathrm{mM}$ dithiothreitol (DTT), and protease inhibitor cocktail tablets (1 tablet per $10 \mathrm{ml}$ buffer)] was added to each tube at $100 \mu \mathrm{l}$ buffer per $1 \times 10^{6}$ cells and mixed well to lyse the cells completely. Lysates were transferred to microcentrifuge tubes, incubated on ice for 10-30 min., and centrifuged at $12,000 \times g$ in a microcentrifuge at $4^{\circ} \mathrm{C}$ for $15 \mathrm{~min}$. The supernatants were collected and stored at $-80^{\circ} \mathrm{C}$ for subsequent analyses. Alternately, Pierce (Rockford, IL) NE-PER Nuclear and Cytoplasmic Extraction Reagents were used as per the manufacturer's protocol for the stepwise separation and preparation of cytoplasmic and nuclear extracts. Protein content was measured using Bradford Reagent. Proteins $(25-30 \mu \mathrm{g})$ were resolved by SDS-PAGE in $12 \%$ SDS-Tris- $\mathrm{HCl}$ polyacrylamide mini-running gels and transferred onto nitrocellulose membranes (BioRad Laboratories; Hercules, CA). Membranes were incubated with primary antibodies to ER $\alpha, E R \beta$, or EGFR at a dilution of 1:1000 in 5\% non-fat dry milk-Tris Buffered Saline/Tween $(\mathrm{TBS} / \mathrm{T})$ buffer at $4^{\circ} \mathrm{C}$ overnight, followed by incubation with both the appropriate horseradish peroxidase (HRP)-conjugated secondary antibody at a dilution of 1:10,000 and anti-biotin antibody at 1:1000 dilution in 5\% non-fat dry milk in TBS/T at room temperature (RT) for $1 \mathrm{~h}$. Protein was detected using the Western Lightning Chemiluminescent Reagent Plus Kit from PerkinElmer (Wellesley, MA) as per the manufacturer's directions. Antibodies $(\mathrm{Ab})$ and controls used were: ER $\alpha$ (62A3) mouse monoclonal Ab, EGFR rabbit polyclonal $\mathrm{Ab}$, and anti-biotin Ab (Cell Signaling Technology; Beverly, MA); ER $\boldsymbol{\beta}$ (PA1-313) rabbit $A b$, human, recombinant ER $\alpha \mathbf{R P}-\mathbf{3 1 0}$ and ER $\beta$ (long form) RP-312 (Affinity BioReagents; Golden, CO); EGF-stimulated A431 cell lysate (Upstate Biotechnology; Lake Placid, NY). Peroxidase-conjugated Immunopure goat anti-mouse and sheep anti-rabbit IgG's were 
used as secondary antibodies (Pierce Chemical Company, Rockford, IL)

\section{E. Gene Expression Analysis of the Human Toxicity/Stress and Estrogen Signaling Pathways}

Cells were trypsinized and pelleted according to the protocol outlined in Section B, and RNA was isolated from cells using the RNAqueous RNA isolation system (Ambion, Inc.; Austin, TX) according to the manufacturer's protocol. Immediately afterwards, contaminating DNA was removed using Ambion's "DNA-free" DNase Treatment and Removal Reagents again as per the manufacturer's directions. The RNA supernatants were transferred to new RNAse-free tubes and stored at $-80 \mathrm{C}$. Prior to use in gene expression studies, the concentration and purity of RNA was determined by aliquoting a small amount of the samples in HPLC-grade, RNase-free $\mathrm{dH}_{2} \mathrm{O}$ and measuring absorbance at $260 \mathrm{~nm}$ and $280 \mathrm{~nm}$. RNA concentration was calculated using a value of $1 \mathrm{~A}_{260 \mathrm{~nm}}=40 \mu \mathrm{g} \mathrm{RNA} / \mathrm{ml}$. and its purity assessed by confirming that the ratio of $A_{260} / A_{280}$ was near 2.0. Nonrad-GEArray Kit Pathway Specific Gene Expression Profiling System (SuperArray, Inc; Bethesda, $\mathrm{MD}$ ) was used for the analysis of gene expression after RNA isolation. The detailed manufacturer's protocol was followed for analysis. Briefly, biotinylated cDNA probes were synthesized from 5-10 $\mu$ g total RNA by reverse transcription using a PCR thermal cycler and SuperArray reagents. Afterwards, cDNA probes were hybridized using a mini hybridization incubator kit reagents to pathway-specific gene expression array membranes (either human toxicity/stress or estrogen signaling) provided by the manufacturer. Finally, membranes were incubated with alkaline phosphatase (AP)streptavidin, and chemiluminescent detection was performed with the provided CDP-Star substrate and immediate exposure to $\mathrm{x}$-ray film between 0-5 min. Signal intensities were quantitated (semi-log) using UN-SCAN-IT digitizing software (Silk Scientific; Orem, UT) after the $\mathrm{x}$-ray films were scanned onto a computer. Sample signal intensities were normalized against a housekeeping gene's signal intensities. Each membrane contained two spots for each cDNA analyzed. Means of the intensity (in pixels) of the duplicate spots were used for analysis

\section{F. Statistical Analysis}

Significance of differences between two groups was assessed using one-tailed Student's " $t$ " test assuming unequal variances. One-way ANOVA followed by Dunnet's test was utilized to compare all groups to a control group, while One-way ANOVA followed by Tukey's test was used to compare all groups to each other. For all tests, $\mathrm{p}<0.05$ was considered significant.

\section{Results}

1. Simultaneous depletion of HC, EGF, and PHR from culture medium is necessary for the morphologic transformation of MCF-10A cells

MCF-10A cells were grown for 5 weeks in continuous culture in 6-well tissue culture plates in PHR-containing or PHR-free medium lacking either one, both, or none of the factors $\mathrm{HC}$ and EGF. Cells in these four types of media were also exposed once a week to either $1 \mathrm{nM} \mathrm{E2}$ or $1 \mathrm{nM} 2$-Fl-E2 in $0.01 \% \mathrm{EtOH}$, or just $0.01 \%$ ethanol $(\mathrm{EtOH})$ as a control. Within five days in culture, cells grown in the presence of $\mathrm{EGF}[+\mathrm{HC} /+\mathrm{EGF}(+/+)$ and $-\mathrm{HC} /+\mathrm{EGF}(-/+)]$ became confluent, whereas those grown in the absence of EGF $[-\mathrm{HC} /-\mathrm{EGF}(-/-)$ and $+\mathrm{HC} /-\mathrm{EGF}(+/-)]$ displayed a slower growth rate. Cells in the $+/$ - medium exhibited the lowest proliferative capacity. Transformed-looking foci were noted to first appear after 13 days in culture and only in PHR-free -/cultures (Fig. 1e-f). After 5 weeks, large, prominent foci became apparent but again, only in PHR-free -/- cultures (Fig. 2e-f). The average number of foci per well of a 6-well tissue culture plate was significantly elevated to $79.5+6.50(\mathrm{p}<0.0005)$ in $-/-$ medium versus 0 in media containing either $\mathrm{HC}$ or EGF (Table 1). An important outcome of these experiments was the observation that the presence of PHR inhibits the appearance of transformed foci (Figs. $1 \& 2$; Table 1 ). To verify that the piled cells observed in Figs. 1 and 2 were live cells and rule out the possibility of artifactual observation, MCF$10 \mathrm{~A}$ cells seeded in triplicate at a density of $6.25 \times 10^{4}$ cells/well in PHR-containing or -deficient -/- medium for 3 weeks in 6-well tissue culture plates were stained with neutral red $(10 \mu \mathrm{g} / \mathrm{ml})$ and photographed. Transformed foci in PHR-deficient -/- medium as well as the monolayer underneath were stained red, confirming the viability of cells both in foci and monolayer (Fig. 3b). The fact that foci were stained deep red while the monolayer was light red suggests piling of cells in foci and proves that foci being observed were not artifacts. Cultures grown in PHR-containing -/- medium did not form foci, as demonstrated by the absence of darkly stained piles of cells (Fig. 3a).

\section{2. $\beta$-Estradiol (E2) elevates the morphologic transformation of MCF-10A cells in -HC/-EGF (-/-) medium, whereas 2-FI-E2 does not}

In an attempt to correlate the transformative and oxidative capacities of E2 within human breast epithelial cells, the MCF-10A cell line was exposed to $1 \mathrm{nM}$ E2 within the four media types already discussed $(+\mathrm{HC} /+\mathrm{EGF}$, $-\mathrm{HC} /-\mathrm{EGF},-\mathrm{HC} /+\mathrm{EGF}$, and $+\mathrm{HC} /-\mathrm{EGF})$. In addition, cells cultured in -/- growth medium were also treated with 2-Fl-E2 to assess the transforming potential of a non-redox cycling estrogen. $+/+,-/+$, and $+/$ - cultures 


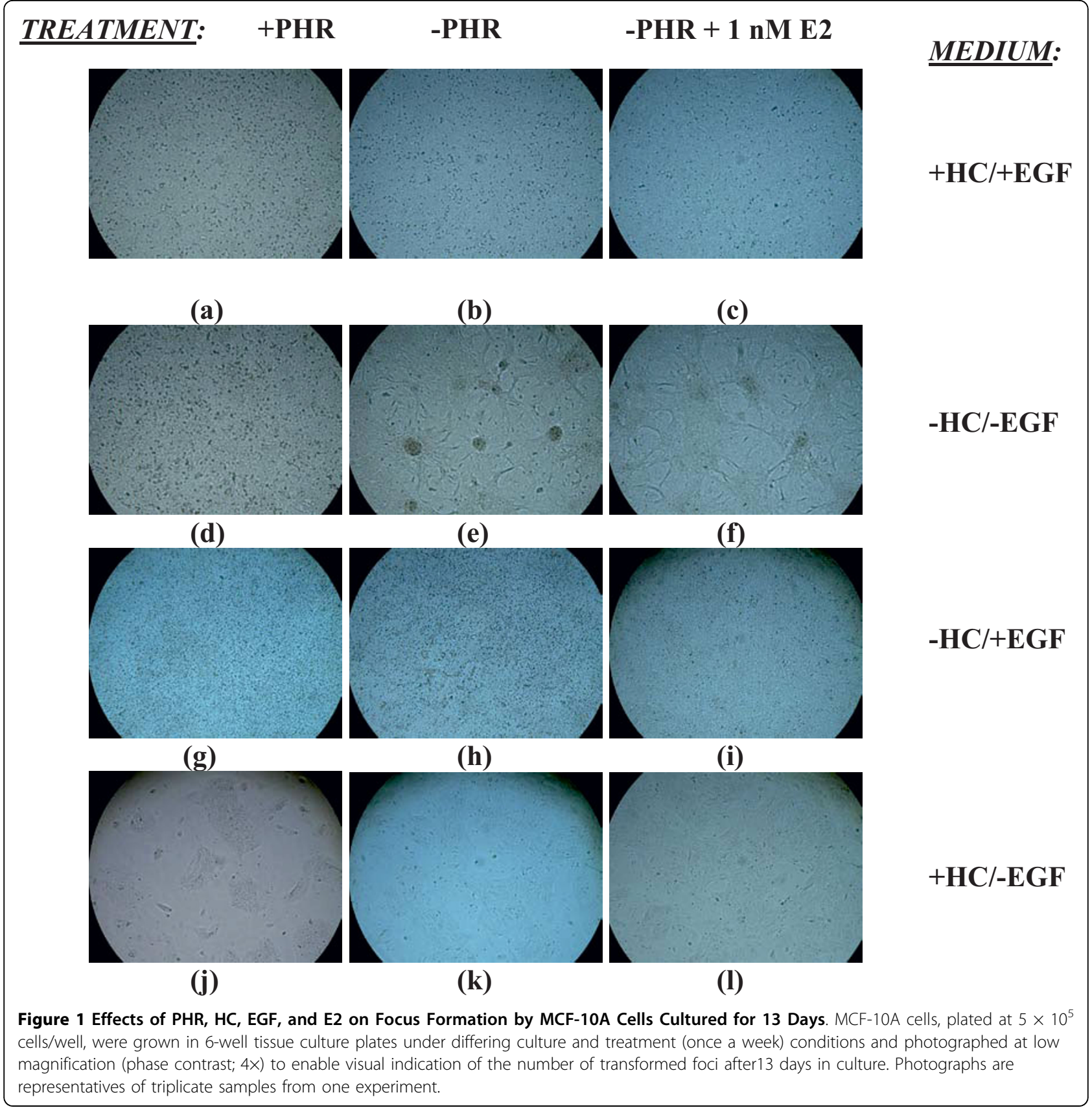

were already shown to be resistant to transformation, since E2 treatment of these cultures did not induce transformation (Figs. $1 \& 2$; Table 1) within the fiveweek treatment protocol. However, transformed foci appeared in E2-treated -/- cultures starting from 13 days of exposure (Fig. 1f). Although at 13 days, foci arising in E2-treated cells were light and less prominent (Fig. 1f) than in non-treated cultures (Fig 1e), by 5 weeks the foci in E2-treated cultures were much denser and larger in size (Fig. 2) than they were at 13 days. While foci sizes in the non-treated cells were still larger in comparison to the E2-treated cultures (Fig. 2e-f) even at 5 weeks, E2 treatment resulted in more numerous foci (Table 1), by over 2-fold in PHR-free -/- cultures in comparison to non-treated controls $(\mathrm{p}<0.0005)$. In contrast to E2, exposure of cells to 2-Fl-E2 in -/- medium did not lead to the appearance of transformed foci at 13 days (data not shown). However, at 5 weeks, transformed foci did appear in 2-Fl-E2-treated -/- cultures within certain wells and/or areas of wells where cellular degradation was apparent (Fig. 4b). In wells/areas of apparent healthy cell growth in 2-Fl-E2-treated cultures, 


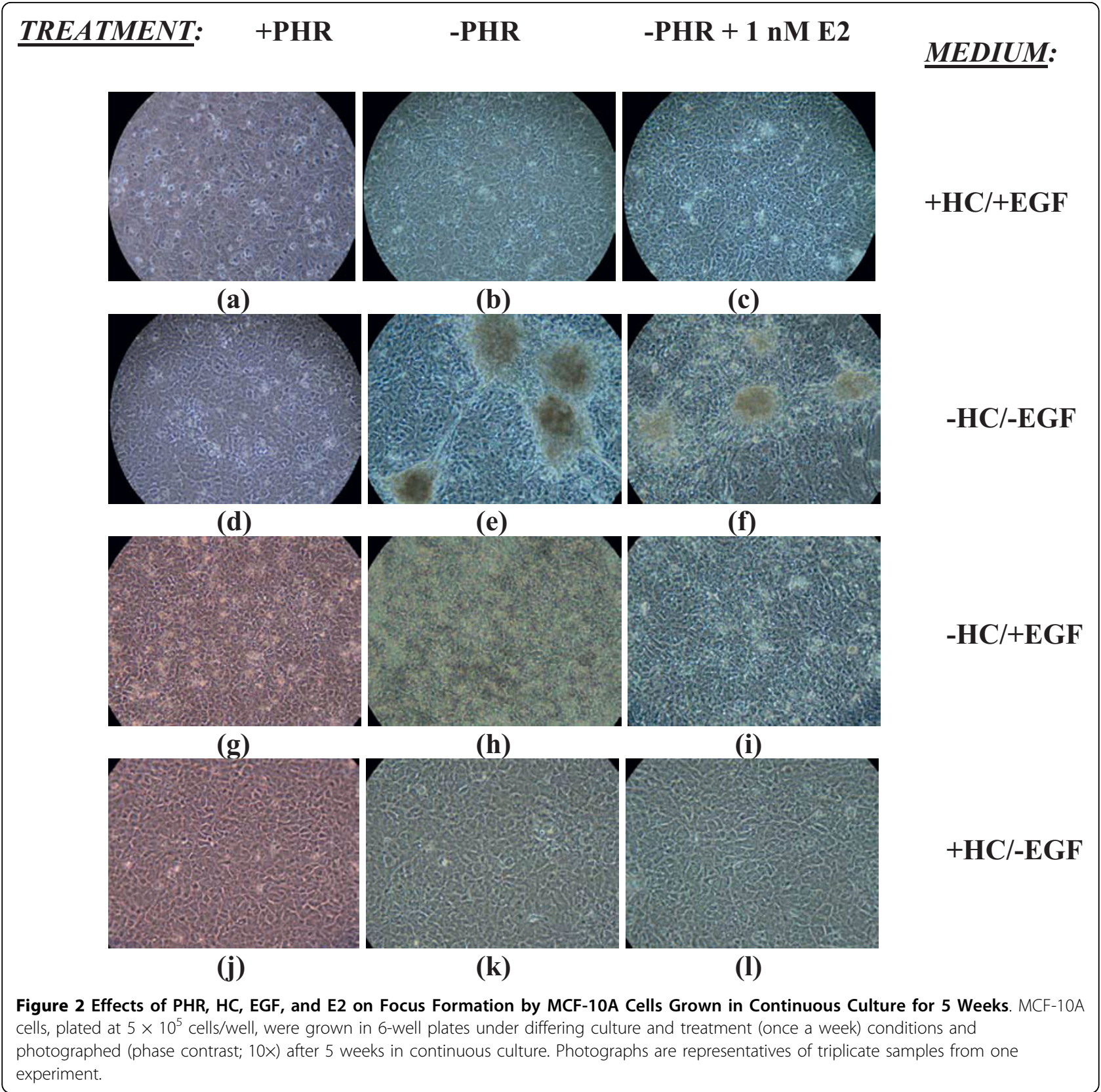

no foci were discernable (Fig. 4a). In contrast, E2-induced foci in -/- cultures formed uniformly among and within wells irrespective of cellular disintegration (Fig. 2f). Nonetheless, the apparently transformed foci in 2-Fl-E2-treated cultures were counted and the total foci number was used as a reliable comparative indicator of transformation potential among treatments. After five weeks of growth, E2 significantly $(\mathrm{p}<0.0005)$ enhanced the transformation of MCF-10A cells in -/- medium in comparison to controls, whereas 2-Fl-E2 was unable to increase the basal transformation rate, as evidenced by the formation of a lower number of foci than in controls (Table 1). E2-treated cells formed over five times the number of foci as $\mathrm{EtOH}$ controls in -/- medium (Table 1).

\section{Re-introduction of HC, but not PHR or EGF,} to -PHR/-HC/-EGF MCF-10A cultures after 5 weeks can partially reverse morphologic transformation

To evaluate whether microenvironmental changes induce irreversible morphologic transformation of MCF10A cells, PHR, HC, or EGF alone as well as $\mathrm{HC}$ and EGF together were re-introduced to - PHR/-HC/-EGF culture medium after the formation of foci in 5 weeks. Microscopic evaluation after 6 weeks revealed no 
Table 1 Effects of PHR, HC, EGF, E2, and 2-FI-E2 on the Appearance of Transformed Foci in MCF-10A Cells after 5 Weeks in Continuous Culture

\begin{tabular}{|c|c|}
\hline Treatments & Number of Foci/Well \\
\hline$(+\mathrm{HC} /+\mathrm{EGF})+\mathrm{PHR}$ & 0.00 \\
\hline (+HC/+EGF) -PHR & 0.00 \\
\hline (+HC/+EGF) -PHR; 1 nM E2 & 0.00 \\
\hline$(-\mathrm{HC} /-\mathrm{EGF})+\mathrm{PHR}$ & 0.00 \\
\hline (-HC/-EGF) -PHR & $79.50+/-6.50^{*, \#}$ \\
\hline (-HC/-EGF) -PHR; 0.01\% EtOH & $33.50+/-27.50$ \\
\hline (-HC/-EGF) -PHR; 1 nM E2 & $182.00+/-2.00^{* *, \Phi}$ \\
\hline (-HC/-EGF) -PHR; 1 nM 2-Fl-E2 & $19.00+/-5.00^{*}$ \\
\hline$(-\mathrm{HC} /+\mathrm{EGF})+\mathrm{PHR}$ & 0.00 \\
\hline$(-\mathrm{HC} /+\mathrm{EGF})-\mathrm{PHR}$ & 0.00 \\
\hline (-HC/+EGF) -PHR; 1 nM E2 & 0.00 \\
\hline$(+\mathrm{HC} /-\mathrm{EGF})+\mathrm{PHR}$ & 0.00 \\
\hline$(+\mathrm{HC} /$-EGF) $-\mathrm{PHR}$ & 0.00 \\
\hline (+HC/-EGF) -PHR; 1 nM E2 & 0.00 \\
\hline
\end{tabular}

Effects of PHR, HC, EGF, E2, and 2-FI-E2 on the appearance of transformed foci in MCF-10A cells after 5 weeks in continuous culture. MCF-10A cells, plated at $5 \times 10^{5}$ cells/well, were exposed to different culture and treatment conditions for 5 weeks in continuous culture. Cells were maintained and treated once a week in 6-well TC plates. The average number of transformed foci/well that appeared at 5 weeks in triplicate wells of each culture/treatment type from one experiment was used for analysis. Significance of differences was analyzed using One-way ANOVA followed by either Dunnet's or Tukey's test. Using One-way ANOVA followed by Dunnet's test: -HC/-EGF/-PHR/E2 vs -HC/-EGF/-PHR/EtOH **p $<0.0005$ -HC/-EGF/-PHR vs -HC/-EGF/-PHR/EtOH *p $<0.05$ Using One-way ANOVA followed by Tukey's test: -HC/-EGF/-PHR/E2 vs all groups ${ }^{\Phi} \mathrm{p}<0.0005$

- HC/-EGF/-PHR vs all groups except - HC/-EGF/-PHR/EtOH ${ }^{\#} \mathrm{p}<0.0005$ obvious changes aside from indications of slightly smaller foci in cultures where either HC or EGF was added (data not shown). Importantly, only the addition of $\mathrm{HC}$ induced a partial $(\sim 40 \%)$ but significant $(\mathrm{p}<0.01)$ decrease in foci numbers (Table 2). Adding back EGF, by itself or with $\mathrm{HC}$, resulted only in a non significant increase in the number of foci.

\section{MCF-10A transformed foci exhibit extensive interconnections while displaying varying morphologies depending on the growth condition}

Slight microenvironmental alterations were seen to profoundly affect the morphology and growth characteristics of MCF-10A human breast epithelial cells. An intriguing characteristic of foci noted in this cell line was the appearance, once foci began to form, of extensive interconnections among them, forming a lattice-like network (Fig. 5a-c). To enable more detailed visualization of transformed foci, $10 \mathrm{nM}$ E2-treated MCF-10A cells were grown in -/- medium until foci formed, trypsinized, and re-plated in poly-d-lysine culture flasks. After 50 days, foci photographed at $40 \times$ magnification enabled the identification of a somewhat polarized eggshaped structure with a distinct, prominent membrane, perhaps of more than one layer, containing the growing contact uninhibited cells within its boundary (Fig. 5d). Growth characteristics of MCF-10A cells grown in the three different types of medium $(+/+,-/-,-/+)$ were examined. Five passages after reaching confluence in their respective medium type, differences among the cells became apparent. Figure 6 shows subconfluent cultures of $+/+,-/-$ (passage \#11), and $-/+$ (passage \#13) cells 24 hours after plating. In contrast to $+/+$ cells, which exhibit normal subconfluent epithelial growth

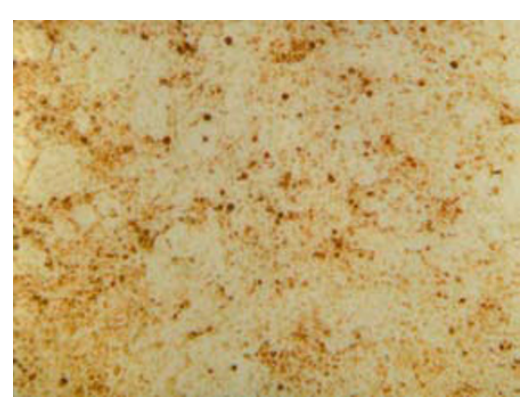

(a) -HC/-EGF; +PHR

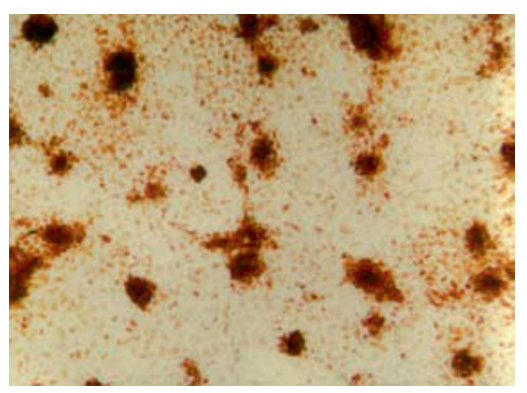

(b) -HC/-EGF; -PHR

Figure 3 Effect of PHR Presence in -HC/-EGF Medium on the Appearance of MCF-10A Transformed Foci After 3 Weeks of Continuous Culture. MCF-10A cells were seeded in triplicate at a density of $6.25 \times 10^{4}$ cells/well in 6-well tissue culture plates and grown in -HC/-EGF medium either with or without phenol red for 3 weeks in continuous culture. Cells were stained with neutral red (10 mg/ml) and photographed (10x obj.). Photographs are representatives of triplicate wells per culture condition from one experiment. 
(a)

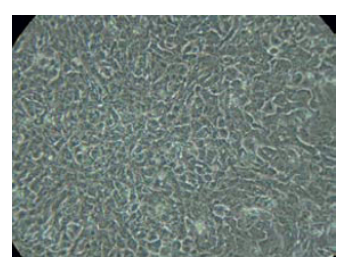

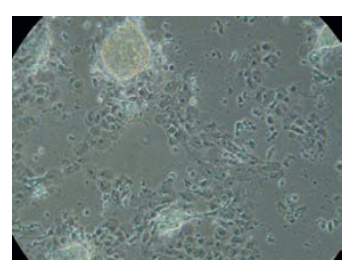

(b)
Figure 4 Effects of $1 \mathrm{nM}$ 2-FI-E2 Treatment on Focus Formation by MCF-10A Cells Grown in Continuous Culture for 5 Weeks. MCF-10A cells, plated at $5 \times 10^{5}$ cells/well, were grown in 6-well TC plates in -PHR/-HC/-EGF medium and treated with $1 \mathrm{nM} 2-\mathrm{FI}-\mathrm{E} 2$ once a week. Two different areas of one well were photographed (phase contrast; 10x) in order to show variations in cell morphology and focus formation within the same treatment group at 5 weeks in continuous culture. Photographs are representatives of triplicate samples from one experiment.

(Fig 6a), -/- cultures already show the presence of small foci growing atop clusters of monolayer cell growth (Fig. 6b). Extensions among foci at this time have already begun to form. MCF-10A -/+ cultures did not form foci at this early time, but displayed a unique morphology of extended, fibroblast-like cells with respect to the other two types of cultures (Fig 6c). Therefore, even a slight microenvironmental alteration can profoundly affect the growth characteristics of human breast epithelial cells, with serious implications regarding their transformation potential.

\section{MCF-10A cells exhibit detectable levels of both ER $\alpha$ and ER $\beta$ gene expression}

The necessity for PHR depletion in our studies indicated a need for ER $\alpha$-mediated events in the transformation of

Table 2 Reversibility of Morphologic Transformation due to Re-addition of PHR, HC, and/or EGF to MCF-10A Cells Grown for 5 Weeks in -PHR/-HC/-EGF Medium

\begin{tabular}{ccc}
\hline Group & Culture Condition & Mean Number of Foci/Well +/- SE \\
\hline \multirow{2}{*}{1} & $-\mathrm{PHR} /$-HC/-EGF & $153.50+/-0.50$ \\
\cline { 2 - 3 } & Add Back PHR & $157.50+/-4.50$ \\
\hline 2 & $-P H R /-H C /-E G F$ & $125.67+/-4.98$ \\
\cline { 2 - 3 } & Add Back HC & $75.33+/-6.74^{*}$ \\
\hline 3 & $-P H R /-H C /-E G F$ & $79.50+/-6.50$ \\
\cline { 2 - 3 } & Add Back EGF & $92.50+/-12.50$ \\
\hline \multirow{2}{*}{4} & $-P H R /-H C /-E G F$ & $145.50+/-12.00$ \\
\cline { 2 - 3 } & Add Back HC \& EGF & $156.50+/-12.50$ \\
\hline
\end{tabular}

MCF-10A cells, plated at $5 \times 10^{5}$ cells/well, were grown in -PHR/-HC/-EGF medium for 5 weeks in 6-well tissue culture plates, at which time cells were re-exposed to depleted agents once for 1 week. Foci were counted at weeks 5 and 6 and the average number of foci/well in 2 wells per re-added agent(s) before and after re-supplementation from one experiment was used to assess reversibility of morphologic transformation. Significance was analyzed using One-way ANOVA followed by Tukey's test.

Add Back HC vs -PHR/-HC/-EGF * $\mathrm{p}<0.01$

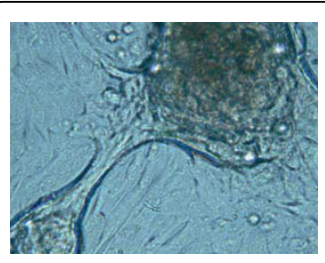

(a) -HC/-EGF; EtOH/DMSO $(0.01 \%) ; 11 \mathrm{~d} ; 20 \mathrm{x}$

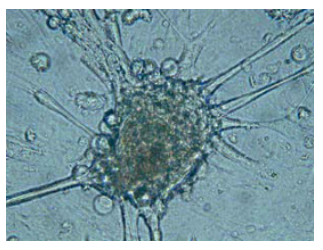

(c) -HC/-EGF; $0.1 \mathrm{nM} \mathrm{E2}$; $11 \mathrm{~d} ; 20 \mathrm{x}$

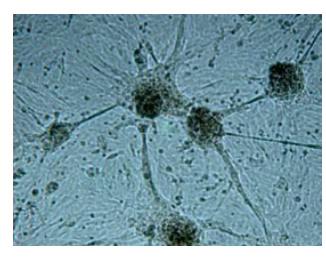

(b) -HC/-EGF; EtOH/DMSO $(0.01 \%) ; 11 \mathrm{~d} ; 4 \mathrm{x}$

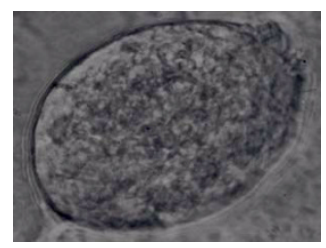

(d) -HC/-EGF; $10 \mathrm{nM} \mathrm{E2;}$

in poly-d-lysine (50d); 40x
Figure 5 Morphology of MCF-10A Transformed Foci. MCF-10A transformed foci, which appear under different culture/treatment conditions, were photographed to document morphologic characteristics. The photograph for panel (d) was taken from a single T25 flask from one experiment. All other photographs are representatives of triplicate wells of 6-well tissue culture plates from one experiment.

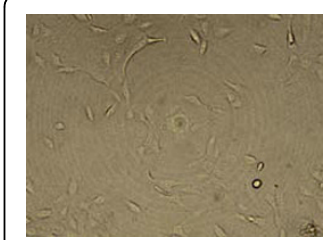

(a) $+\mathrm{HC} /+\mathrm{EGF} ; 10 \mathrm{x}$

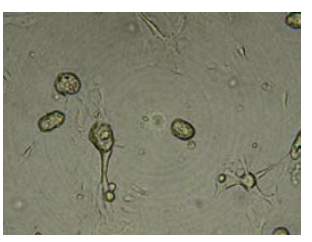

(b) -HC/-EGF \#11;10x

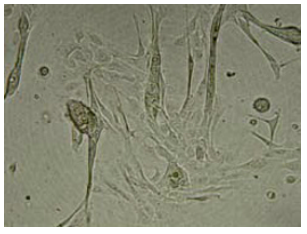

(c) $-\mathrm{HC} /+\mathrm{EGF} \# 13 ; 10 \mathrm{x}$

Figure 6 Effect of HC and/or EGF Withdrawal on MCF-10A Cell Growth and Morphology in PHR-Free Medium after $24 \mathrm{~h}$ Culture. MCF-10A cells were either maintained in fully supplemented medium (+HC/+EGF), grown in HC/EGF-depleted medium (-HC/-EGF) for 11 passages, or grown in HC-deficient medium (-HC/+EGF) for 13 passages. Cells grown in different media types were photographed under phase-contrast microscopy 24 hours after plating. Photographs are representatives of triplicate samples of each culture condition from one experiment. 
Table 3 Estrogen Receptor Gene Expression in MCF-10A Cells Under Various Treatment and Culture Conditions

\begin{tabular}{|c|c|c|c|}
\hline Group & $\begin{array}{l}\text { Culture/Treatment } \\
\text { Conditions }\end{array}$ & $\begin{array}{c}\text { ER } \alpha \text { (Mean Gene } \\
\text { Expression) }\end{array}$ & $\begin{array}{c}\text { ER } \beta \text { (Mean Gene } \\
\text { Expression) }\end{array}$ \\
\hline \multirow[t]{2}{*}{1} & $+\mathrm{HC} /+\mathrm{EGF} ; \mathrm{NT}$ & 62.75 & 9.86 \\
\hline & -HC/+EGF (\#21); NT & 57.98 & 5.88 \\
\hline \multirow[t]{2}{*}{2} & $+\mathrm{HC} /+\mathrm{EGF} ; \mathrm{NT}$ & 59.79 & 15.82 \\
\hline & -HC/-EGF (\#1); 1 nM E2 & 57.48 & 10.21 \\
\hline \multirow[t]{2}{*}{3} & -HC/-EGF (\#1); NT & 50.77 & a \\
\hline & -HC/-EGF (\#1); 1 nM E2 & 53.96 & a \\
\hline
\end{tabular}

ER gene expression in MCF-10A cells maintained in and exposed to various culture/treatment conditions was assessed using a human estrogen signaling pathway-specific gene expression profiling system (SuperArray, Inc; Bethesda, MD) as described in the Methods section. Results shown are those of three different experiments comparing two different culture conditions at a time and using 5-10 $\mu \mathrm{g}$ total RNA. MCF-10A cells grown in culture media either containing or lacking HC/EGF were either left non-treated (NT) or treated twice a week with $1 \mathrm{nM}$ E2 for 2 weeks. Numbers in parentheses indicate the number of passages in that particular medium type. Mean signal intensity (pixels $\times 10^{-4}$ ) values from duplicate spots of both ER $\alpha$ and $\operatorname{ER} \beta$ per membrane were normalized against those of a housekeeping gene and taken to be representative of mean gene expression.

a) Signal too weak to evaluate

MCF-10A cells. PHR's known weak estrogenicity and binding to ER $\alpha[32,33]$ may suppress receptor's binding of E2, thereby preventing the relatively more potent hormonal and/or oxidative properties of E2 from effecting transformation. Although this cell line is categorized as $E R \alpha$-negative, our results made it necessary to re-examine the ER $\alpha$ status of these cells. A commercially available gene expression array kit (SuperArray; Bethesda, MD) was utilized for the analysis of human estrogen signaling pathway gene expression in non-treated and $1 \mathrm{nM}$ E2-treated (twice a week for 2 weeks) MCF-10A cells grown under various media conditions. Table 3 demonstrates detectable gene expression of both ER $\alpha$ and ER $\beta$ among the different growth and treatment conditions for MCF-10A cells assessed. ER $\alpha$ gene expression was consistently higher in comparison to ER $\beta$ expression levels. Although no indicative trends and/or upregulation in ER expression due to varying treatments and culture conditions was noted, the data demonstrate persistent, detectable levels, particularly of ER $\alpha$ gene expression, in this cell line.

\section{Western blotting confirms the presence of $E R \alpha$ and} ER $\beta$ in MCF-10A cells; Possibility of a direct association of $E R \alpha$ and EGFR, with induction of a putative ternary complex composed of ER $\alpha / E R \beta / E G F R$ in those cells that are the most prone to transformation

MCF-10A cells maintained in different growth conditions and those acquired from various laboratories were subjected to Western blotting analysis for $E R \alpha, E R \beta$, and EGFR expression (Fig. 7). Nuclear extracts from 16 samples containing $42 \mu \mathrm{g}$ protein were electrophoresed onto two $12 \%$ SDS-Tris- $\mathrm{HCl}$ polyacrylamide gels (gel 1: Fig. 7a, c, e \& gel 2: Fig. 7b, d, f) and transferred to nitrocellulose membranes. The two membranes were then probed consecutively with antibodies directed against ER $\alpha$ (Fig. 7a \&7b), ER $\beta$ (Fig. 7c \&7d) and EGFR (Fig. 7e \&7f). The first three lanes of both gels contain, respectively, control human recombinant proteins ER $\alpha$ and ER $\beta$ from baculovirus-infected Sf9 cells, and total cell lysate from EGF-stimulated A431 cells (positive control for EGFR) (Fig. 7a-f; lanes 1-3 \& 9-11). All other lanes contain MCF-10A sample nuclear extracts. Membranes were first probed with antibodies directed against $\mathrm{ER} \alpha$, which detect a $66 \mathrm{kD}$ protein. These blots are depicted in Figure 7a-b and appear to show very light but detectable bands at $66 \mathrm{kD}$ in all MCF-10A sample lanes (Fig. 7a-b; lanes 4-8 \& 12-16) corresponding to $E R \alpha$, as corroborated by staining in this region in the ER $\alpha$ positive control (Fig. 7a-b; lanes $1 \& 9$ ). Bands are absent in the lane containing recombinant ER $\beta$ protein (Fig. 7a-b; lanes 2 \& 10), verifying the absence of nonspecific binding. Interestingly, EGFR control cell extracts from A431 cells also appear to indicate the presence of even lighter, but still detectable bands at $66 \mathrm{kD}$ (Fig. 7ab; lanes 3 \& 11). A431 are not known to express ERa, but such a possibility is suggested by observed growth inhibition by the antiestrogen tamoxifen [34] and growth stimulation by the estrogenic compound genistein [35] in A431 cells. The same two membranes were re-probed with antibodies directed against ER $\beta$ (Fig. 7cd). Bands around $60 \mathrm{kD}$ appear to be present in the lane containing the recombinant ER $\beta$ (Fig. 7c-d; lanes 2 \& 10 ), which has a molecular weight of 59.2 , and in all other MCF-10A samples tested (Fig. 7c-d; lanes 4-8 \& 12-16). Bands are not present in the lane containing recombinant ER $\alpha$ (Fig. 7c-d; lanes 1 \& 9), again confirming the absence of non-specific antibody binding. A431 control cell extracts do not show the presence of ER $\beta$ (Fig. 7c-d, lanes $3 \& 11$ ) as they did ER $\alpha$ (Fig. 7a-b; lanes 3 \& 11). Re-probing the gels with antibodies directed against EGFR (Fig. 7e-f), which detect the protein at $\sim 175 \mathrm{kD}$, indicates the presence of bands between 140 and $200 \mathrm{kD}$, again in all MCF-10A samples (Fig. 7e-f; lanes 4-8 \& 12-16) and in the EGF-stimulated A431 cell extracts (Fig. 7e-f; lanes $3 \& 11$ ), which serve as a positive control for EGFR. Bands are not seen in lanes containing human recombinant ER $\alpha$ (Fig. 7e-f; lanes 1 \& 9) or ER $\beta$ (Fig. 7e-f; lanes $2 \& 10$ ). These data taken together appear to confirm the presence of $E R \alpha, E R \beta$, and EGFR in all MCF-10A samples tested, even in those obtained from different laboratories, and suggest the possible presence of ER $\alpha$ in the human squamous cell carcinoma line A431. What is even more intriguing in these Western blots is the presence of a band at 


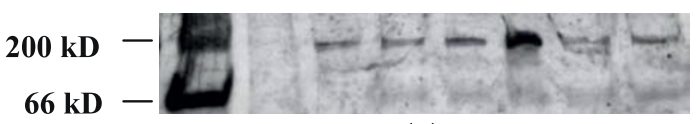

(a)

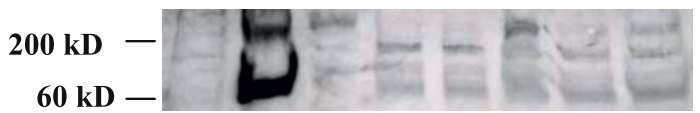

(c)

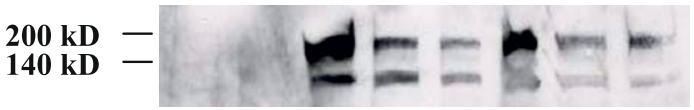

(e)

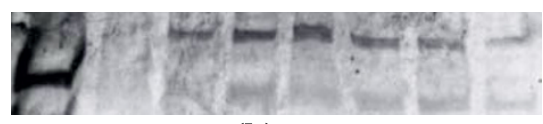

(b)

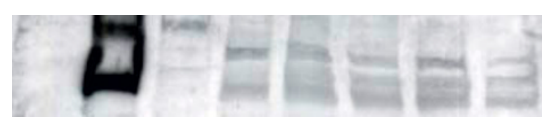

(d)

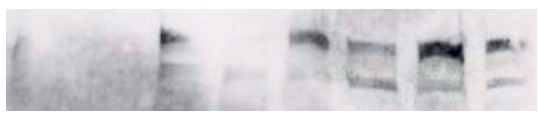

(f)

$$
\begin{array}{lllllllllllllllll}
1 & 2 & 3 & 4 & 5 & 6 & 7 & 8 & & 9 & 10 & 11 & 12 & 13 & 14 & 15 & 16
\end{array}
$$

\section{Lanes:}

1 - Human Recombinant ER- $\alpha$ From Baculovirus-Infected Sf9 Cells

2 - Human Recombinant ER- $\beta$ From Baculovirus-Infected Sf9 Cells

3 - EGF-Stimulated A431 Total Cell Extracts (positive control for EGFR)

4 - MCF-10A $[+/+]$

5 - MCF-10A [-/- (\#1)]

6 - MCF-10A [-/- (\#28)]

7 - MCF-10A $[-/+(\# 2)]$

8 - MCF-10A [-/+ (\#71)]

9 - Human Recombinant ER- $\alpha$ From Baculovirus-Infected Sf9 Cells

10 - Human Recombinant ER- $\beta$ From Baculovirus-Infected Sf9 Cells

11 - EGF-Stimulated A431 Total Cell Extracts (positive control for EGFR)

12 - MCF-10A $[+/+]$ (Newly Acquired from ATCC)

13 - MCF-10A $[+/+]$ (Source \#4)

14 - MCF-10A $[+/+]$ (Source \#3)

15 - MCF-10A $[+/+] \quad$ (Source \#2)

16 - MCF-10A $[+/+]$ (Source \#1)

Figure 7 Analysis of MCF-10A Cells for ER $\alpha$, ER $\beta$, and EGFR. Nuclear proteins extracted from MCF-10A cells that were exposed to differing culture conditions were analyzed by Western blotting for the presence of ER $\alpha$, ER $\beta$, and EGFR. Numbers in parentheses indicate the number of passages in that particular type of medium. Proteins ( $42 \mu \mathrm{g} / \mathrm{lane}$ ) were electrophoresed onto two $12 \%$ Tris- $\mathrm{HCl}$ gels (lanes 1-8 and 9-16

respectively) and transferred onto nitrocellulose membranes. Membranes were probed with antibodies directed against ER $(\mathrm{a}$ and b), stripped and re-probed with antibodies directed against ER $\beta$ ( $c$ and $d$ ), and stripped a second time and re-probed with antibodies directed against EGFR (e and f). Results shown are those from one experiment.

$\sim 200 \mathrm{kD}$ in all MCF-10A samples and A431 samples that is detected by antibodies directed against both EGFR and ER $\alpha$ (Fig. 7a-b \&7e-f; lanes 3-8 \& 11-16). This band appears to be induced in MCF-10A cells grown for 28 passages in HC- and EGF-depleted medium (Fig. 7a \& e; lane 6). This band is not seen only in the photograph (Fig. $7 \mathrm{f}$, lane 12), but is present as an extremely faint band in the original $\mathrm{x}$-ray film of the newly acquired MCF-10A cells grown in $+/+$ medium. While highly speculative, an association between EGFR and ER $\alpha$ in both MCF-10A and A431 cells, which is upregulated in MCF-10A -/- \#28 cells is one possible explanation for these results. Interestingly, in blots which were analyzed with ER $\beta$ antibodies (Fig. 7cd), this $\sim 200 \mathrm{kD}$ band is apparent only in A431 (Fig. 7c-d; lanes 3 \& 11), MCF-10A -/- \#28 (Fig. 7c; lane 6), and MCF-10A -/+ \#71 (Fig. 7c; lane 8) cells. Again, one possible explanation for this, which will need to be explored further in order to be confirmed, is the existence of a ternary association of ER $\alpha / E R \beta / E G F R$ unique to these particular cells. The absence of detectable ER $\beta$ at $\sim 60 \mathrm{kD}$ (Fig. $7 \mathrm{c}$-d; lanes 3 \& 11) in A431 cells may be an indication of low levels of ER $\beta$ in these cells which preferentially associate with EGFR/ER $\alpha$ complex. Overall, however, Western blot analysis appeared to demonstrate detectable levels of $E R \alpha, E R \beta$, and EGFR in MCF-10A cells grown under various culture conditions in our lab and those obtained from a variety of sources. These data also initiate speculation of a direct association of EGFR and ER $\alpha$ in MCF-10A cells. 
MCF-10A cells grown long-term in HC/EGF-depleted medium (-/ - \#28) appear to display a high induction of this complex but with the added presence of ER $\beta$. This putative ternary complex is also slightly induced in MCF$10 \mathrm{~A}$ cells chronically depleted of $\mathrm{HC}$ and propagated for a longer time $(-/+\# 71)$, presented in lane 8.

\section{Modulation of ER-responsive genes in MCF-10A cells by E2 and redox manipulation}

In support of the role of an active ER $\alpha$ component in MCF-10A cell transformation, Table 4 demonstrates that $1 \mathrm{nM}$ E2 treatment of -/- MCF-10A cultures upregulated prolactin (PRL) gene expression by over 6 -fold, which was statistically significant $(\mathrm{p}<0.05)$, while it down-regulated progesterone receptor (PR) gene expression by over 2 -fold, suggesting hormonal estrogen responsiveness of this cell line. PRL gene expression was also seen to be modulated in the presence of EGF by the long-term depletion of $\mathrm{HC}$, where $-/+(\# 21) \mathrm{MCF}$ $10 \mathrm{~A}$ cells exhibited a decrease in PRL gene expression by 4 -fold $(\mathrm{p}<0.05)$ in comparison to $+/+$ cultures (Table 5). Expression of several other genes involved in the estrogen signaling pathway was also modulated in response to the chronic depletion of HC from MCF10A culture medium (Table 5). Expression of the genes c-fos and c-jun was diminished by nearly 2 - and over 3 fold, respectively, while c-myc expression was abrogated entirely. ER-binding fragment-associated antigen9 (EBAG9) and EGF gene expression were downregulated by over 4 -fold each, while $\mathrm{H}$-ras by 3 -fold.

\section{Discussion}

The mandatory depletion of $\mathrm{HC}$, a potent anti-inflammatory agent thought to decrease oxidative stress in cells, in order to transform cells suggests that an oxidant

Table 4 Comparison of Progesterone Receptor and Prolactin Gene Expression in 1 nM E2-Treated versus Non-treated MCF-10A -HC/-EGF (\#1) Cells

\begin{tabular}{cccc}
\hline Group & Gene & $\begin{array}{c}\text { Gene Expression in } \\
-\mathrm{HC} / \text {-EGF (\#1) Cells } \\
\text { (Non-Treated) }\end{array}$ & $\begin{array}{c}\text { Gene Expression in } \\
-\mathrm{HC} / \text {-EGF (\#1) Cells } \\
\text { (1 nM E2) }\end{array}$ \\
\hline 1 & $\mathrm{PR}$ & 5.17 & 2.27 \\
\hline 2 & $\mathrm{PRL}$ & 0.82 & $5.52^{*}$ \\
\hline
\end{tabular}

MCF-10A cells maintained in $+\mathrm{HC} /+\mathrm{EGF}$ medium were grown for 1 passage in -HC/-EGF medium and either left not treated (NT) or were treated twice a week for 2 weeks with $1 \mathrm{nM}$ E2. Gene expression analysis of genes involved in the human estrogen signaling pathway in MCF-10A cells grown under these two treatment conditions were compared using a gene expression profiling system (SuperArray, Inc; Bethesda, MD) as described in the Methods section. Mean signal intensity (pixels $\times 10^{-4}$ ) values from duplicate spots of each CDNA per membrane were normalized against those of a housekeeping gene and taken to be representative of mean gene expression. Results shown are those of one experiment comparing two different treatment conditions. Significance of differences between expression of PR and PRL genes in MCF10A -HC/-EGF (1 nM E2) cultures versus expression of their respective controls in MCF-10A -HC/-EGF (NT) cultures was analyzed using one-tailed Student's " $\mathrm{t}$ " test assuming unequal variances. ${ }^{*} \mathrm{p}<0.05$
Table 5 Comparison of Estrogen Signaling Pathway Gene Expression in MCF-10A -HC/+EGF (\#21) versus +HC/+EGF Cells

\begin{tabular}{clcc}
\hline Group Gene & $\begin{array}{c}\text { Mean Gene Expression } \\
\text { in } \\
\text { +HC/+EGF }\end{array}$ & $\begin{array}{c}\text { Mean Gene Expression } \\
\text { in } \\
\text {-HC/+EGF \#21 }\end{array}$ \\
\hline 1 & c-fos & $22.50+/-4.70$ & $12.36+/-3.37$ \\
\hline 2 & c-jun & $11.87+/-2.78$ & $3.83+/-2.20$ \\
\hline 3 & c-myc & $2.20+/-0.03$ & $0.00+/-0.00^{* *}$ \\
\hline 4 & EBAG9 & $8.11+/-3.2$ & $1.82+/-0.79$ \\
\hline 5 & EGF & $8.05+/-2.98$ & $2.08+/-0.25$ \\
\hline 6 & H-ras & $6.75+/-1.35$ & $1.95+/-1.85$ \\
\hline 7 & PRL & $32.19+/-2.42$ & $8.57+/-0.16^{*}$ \\
\hline 8 & pS2 & $1.16+/-0.91$ & $3.73+/-1.84$ \\
\hline
\end{tabular}

MCF-10A cells maintained in +HC/+EGF medium were either kept in this medium or subsequently grown for 21 passages in -HC/+EGF medium. Gene expression analysis of genes involved in the estrogen signaling pathway in MCF-10A cells grown in these two media types were compared using a gene expression profiling system (SuperArray, Inc; Bethesda, MD) as described in the Methods section. Mean signal intensity (Pixels $\times 10^{-4}$ ) values from duplicate spots of each cDNA per membrane were normalized against those of a housekeeping gene and taken to be representative of mean gene expression. Results shown are those of one experiment comparing two different culture conditions. Significance of differences between expression of each gene in MCF-10A - HC/+EGF \#21 cultures versus expression of its respective control in MCF-10A + HC/+EGF cultures was analyzed using onetailed Student's " $\mathrm{t}$ " test assuming unequal variances. ${ }^{*} \mathrm{p}<0.05,{ }^{* *} \mathrm{p}<0.005$

milieu is critical to the carcinogenic process (Figs. 1 \&2). However, re-addition of $\mathrm{HC}$, significantly $(\mathrm{p}<0.01)$, but only partially, reversed the morphologic transformation seen in 5-week -/- MCF-10A continuous cultures (Table 2). The inhibitory effect of added HC on cell transformation and the reversible nature of its action have been documented in various cell types [36-38]. For example, the presence of $\mathrm{HC}$ reversibly mediated growth inhibition as well as anchorage-dependence of rat $\mathrm{C} 6$ glioma cells and blocked colony formation in agarose [36,37]. HC-mediated ROS suppression [39,40], decrease of nuclear NF- $\kappa \mathrm{B}[41]$, and increases in antioxidant enzymes [42] are likely responsible for such transformation-retarding effects.

Transformation of MCF-10A cells, however, was also dependent on the simultaneous depletion of EGF from the culture medium (Figs. 1 \&2); hence, EGF withdrawal-mediated ROS generation could play a role in such transformation. In mouse proximal tubular (MPT) cells, EGF deprivation was shown to elevate cellular superoxide anion radical levels and induce apoptosis [43]. However, by itself, EGF can trigger $\mathrm{H}_{2} \mathrm{O}_{2}$ production $[7,8]$ and thus, the finding that its presence inhibits transformation supports the possible outgrowth of EGF-independent clones and suppression of EGFR activity as important events in the transformation pathway $[44,45]$ as well. In fact, adding back EGF, both by itself or with $\mathrm{HC}$ resulted in a slight increase in the number of foci (Table 2) and points to the possible outgrowth of 
EGF-autonomous cells, which then become hypersensitive to the action of EGF perhaps due to the acquisition of a constitutively active EGFR pathway. Lack of EGF in cell culture medium has previously been linked to the spontaneous transformation of HMT-3522 cells [46,47], to carcinogen-initiated neoplastic transformation of Syrian golden hamster pancreatic duct cells [48], and to benzo[a]-pyrene (BP)-enhanced cell proliferation in MCF-10A cells [49].

Our studies showed that transformation rates of MCF$10 \mathrm{~A}$ cells treated with $1 \mathrm{nM}$ E2 were elevated by over 5 -fold in comparison to those of EtOH controls, only within a pre-existing oxidant microenvironment generated by $\mathrm{HC}$ and, possibly, EGF depletion (Table 1). The probability that E2-mediated transformation relies on the generation of ROS is indicated by the observation that $1 \mathrm{nM} 2$-Fl-E2, an estrogen whose metabolism leads to the formation of lower levels of oxidants [4,25-27,50], is incapable of increasing transformation in MCF-10A cells over EtOH controls (Table 1). Studies previously conducted in animals and in various cell models implicate estrogens in transformation, ROS generation, and oxidative DNA damage, particularly 8-OHdG $[25,28,30-32,51,52]$. Yet, our data also implicated estrogen receptor-mediated effects on cellular transformation. MCF-10A cells exposed to E2 are refractory to transformation even in the absence of $\mathrm{HC}(-/+$ cultures $)$ but in the presence of EGF (Figs. 1 \&2; Table 1), implying a need for the possible upregulation of ER- $\alpha$, due to EGF withdrawal, within the carcinogenic process in this model. Low EGF concentrations in a low serumcontaining medium stimulated growth of high ER $\alpha$ expressing human breast cancer cell lines A431 and BT20, while high EGF doses inhibited their growth [53]. Taken together, the data implicate EGF independence and E2-generated ROS and/or ER $\alpha$-mediated events as possible contributors to MCF-10A transformation.

The presence of ER $\alpha$ in this ER $\alpha$-negative categorized cell line and its importance in transformation is underscored by observed transformation suppression in the presence of PHR (Figure 3; Table 1) at 5 days (data not shown), 13 days (Fig. 1), and 5 weeks (Fig. 2). PHR, a known weak estrogen $[32,33]$ used as a $\mathrm{pH}$ indicator at a concentration of $15-45 \mu \mathrm{M}$ in most tissue culture media, can bind to the ER $\alpha$ of MCF-7 human breast cancer cells at an affinity of $0.001 \%$ of E2 and was seen to reduce $E R \alpha$-mediated growth stimulatory processes of exogenous estrogens [32]. The PHR concentration of media used in the present study $(21.5 \mu \mathrm{M})$ could, therefore, effectively have blocked E2-mediated hormonal and/or oxidative effects on foci formation, as was observed. MCF-10A cells are normally cultured in medium supplemented with horse serum (HS), which contains estradiol. It is possible that chronic exposure of
MCF-10A cells to picomolar $\left(\sim 6 \times 10^{-12} \mathrm{M}\right)$ estradiol contained in HS led to upregulated ER $\alpha$ expression and contributed in part to the transformation of MCF-10A cells seen in -/- medium even in the absence of added E2 (NT and ethanol controls). We found that ER $\alpha-$ mediated events in MCF-10A cell transformation most likely constitute irreversible alterations since re-introducing PHR to culture medium had no effect on the number of foci, once formed (Table 2).

Gene expression arrays confirmed the expression of both ER $\alpha$ and ER $\beta$ in MCF-10A cells (Table 3) as well as estrogen responsive genes (Tables $4 \& 5$ ). The persistent, detectable levels of ER $\alpha$ and ER $\beta$ observed among varying culture conditions and treatments (Table 3 ), even in cells newly purchased from ATCC, provide evidence contradicting the classification of the MCF-10A cell line as ER $\alpha$-negative. Hormonal estrogen responsiveness was also indicated by the observation that a $1 \mathrm{nM}$ E2 treatment of -/- MCF-10A cultures upregulated prolactin (PRL) gene expression by $>6$-fold, while it down-regulated progesterone receptor (PR) gene expression by $>2$-fold (Table 4 ). Such modulation has important implications for mammary cell differentiation/proliferation and cancer development. Pituitary prolactin levels are known to be increased due to exposure to exogenous estrogens [54], promote mammary cancer in rats and mice [55] and can activate Ras in rat lymphoma cells [56] with recent studies linking circulating levels to breast cancer [57]. PR, as well, is known to induce mammary epithelial cell proliferation $[58,59]$ and contribute to mammary tumorigenesis [58]. Similar to our findings, suppression of PR gene expression in human breast epithelial cells ML-20 and KPL-1 within a hypoxic microenvironment promoted malignancy [60]. Interestingly, we noted that $\mathrm{HC}$ withdrawal was noted to modulate expression of estrogen responsive genes pS2, EBAG9, and PRL and genes involved in estrogen signaling such as EGF, c-fos, c-jun, c-myc, and H-ras (Table 5), which may be the result of an attempt by the cell to combat oxidative stress-induced cellular transformation.

The reasons for down-regulated EGF expression due to $\mathrm{HC}$ withdrawal are unclear. However, the presence of EGF inhibited MCF-10A foci formation even when cells were continuously treated with E2 (Table 1). EGF withdrawal was previously documented to transform human breast epithelial cell line HMT-3522, where EGFR suppression was posited to promote estrogen-responsive breast cancer $[44,45]$. As well, low EGF levels present in low serum-containing medium stimulated growth of human breast cancer cell lines A431 and BT20, expressing high ER $\alpha$ levels, while high EGF concentrations inhibited cell growth [53]. Interestingly, in EGF-depleted MCF-10A cells, increased ROS generation due to benzo 
[a]pyrene-quinone (BPQ) exposure was seen to activate EGFR [49]. In other studies, redox regulation of ER was also apparent, where $\mathrm{H}_{2} \mathrm{O}_{2}$-induced oxidative stress in MCF-7 and T-47 D human breast cancer cells led to a minimal upregulation of ER- $\alpha$ but a significant increase in ER- $\beta$ levels [61]. The initial depletion of HC and EGF from the growth medium of MCF-10A cells could lead to the upregulation of ER expression due to both EGF withdrawal-mediated effects and elevated oxidative stress. At the same time, increased oxidant levels concomitant with EGF-withdrawal may also activate EGFR in these cells. EGF hypersensitivity was already noted in our system (Table 2).

Further support for increased ER and EGFR activities due to increased oxidative stress and concomitant EGF withdrawal was provided by the possible existence of a novel, yet still highly speculative, direct association of EGFR and ER $\alpha$ in MCF-10A seen to be induced and believed to include the presence of ER $\beta$ in chronic $\mathrm{HC} /$ EGF-depleted MCF-10A cells (Fig. 7), which are the most prone to transformation. A puzzling observation in the Western blots showing this ternary complex formation is the presence of the $\sim 200 \mathrm{kD}$ band in lanes containing the recombinant proteins $E R \alpha$ and $E R \beta$ synthesized in baculovirus-infected Sf9 cells (Fig. 7a-b; lanes $1 \& 9$ and Fig. 7c-d; lanes 2 \& 10). This observation can only be explained by copurification of these recombinant proteins with contaminating host EGFR proteins. Yet, Sf9 are insect spodoptera frugiperda cells do not contain human EGFR. However, Sf9 cells do contain a growth-blocking peptide receptor (GBPR) having a tyrosine phosphorylation subunit, which can bind human EGF, and can be detected in gels by probing with anti-human EGFR antibody [62]. Thus, association of GBPR with ER $\alpha$ or ER $\beta$ during their synthesis in Sf9 cells would explain the presence of the $\sim 200 \mathrm{kD}$ band in bands containing the recombinant proteins and probed with their respective antibodies. Detection of the $\sim 200 \mathrm{kD}$ band in lanes containing both recombinant $E R \alpha$ and ER $\beta$ indicate that GBPR can associate with both proteins, yet these bands would not cross-react with both ER $\alpha$ and ER $\beta$ antibodies, as seen, since only one protein would be synthesized at a time in Sf9 cells. The absence of a $\sim 200 \mathrm{kD}$ band in lanes containing recombinant ER $\alpha$ or ER $\beta$ in gels probed with EGFR antibodies (Fig. 7e-f; lanes 1-2 \& 9-10) may be due to the fact that the EGFR moiety detected by the particular EGFR antibody used is not present in GBPR.

Induction of this, as yet speculative, ER $\alpha / E R \beta / E G F R$ ternary complex formation may provide an explanation and plausible mechanism for the increased EGF and E2 sensitivity noted in the transformation of this cell line. Chronic withdrawal of HC/EGF from MCF-10A cell cultures seems to strongly facilitate the formation of this putative ER $\alpha / E R \beta / E G F R$ ternary complex, a possible manifestation of the ER and EGFR upregulation induced by increased ROS and EGF deficiency in the microenvironment, thereby conferring both EGF and E2 hypersensitivity to cells. While work by other laboratories have implicated either ER or EGFR upregulation/activation due to the actions of EGF withdrawal and increased oxidative stress either by themselves or together, the present study indicates increased activation of both ER and EGFR in the MCF-10A cell line due to the simultaneous effects of both increased oxidant stress and EGF withdrawal. The transformation-enhancing action of such EGF and E2 hypersensitivity can be mediated by the induction of this possible ER $\alpha / E R \beta / E G F R$ ternary complex noted to occur under EGF-deficient, pro-oxidant conditions. Marquez et al. have also demonstrated a novel direct interaction between ER and EGFR after EGF treatment of MCF-7 cells where EGFR tyrosine kinase phosphorylates ER $\alpha$ at tyrosine-537 and tyrosine43 , possibly leading to estrogen-independent activation of ER-mediated transcription and cell proliferation $[63,64]$. Others have reported similar results [65]. Proteins recognized by ER- $\alpha$ and ER- $\beta$ monoclonal antibodies were found in close association to EGFR in lung tumor cells [66]. As well, estrogen was seen to promote an association between extranuclear ER- $\alpha$ and the EGFR family member ERBB4 in the T47 D breast cancer cell line [67]. Such cross-talk can activate diverse downstream signal transduction pathways which regulate cell proliferation $[66,68]$. In addition, bi-directional cross talk between ER and EGFR can enhance the individual actions of steroids [69]. Thus, augmented cell proliferation and survival responses [14,63,70-72] due to ER/ EGFR interactions in MCF-10A cells can possibly lead to their transformation. Several laboratories have posited the probable co-existence and/or necessity for ERmediated proliferative effects and CE-mediated genotoxic and oxidative events in carcinogenic process $[20,73,74]$. Results from the present study indicate this to be the case in the transformation of MCF-10A cells.

\section{Conclusions}

A model for the transformation of human breast epithelial cells MCF-10A (Fig. 8) is proposed where initial chronic HC/EGF-deprivation increases ROS formation leading to elevated oxidative stress and resultant oxidative DNA damage-induced gene mutations. At the same time, the depletion of HC and EGF induce ER upregulation along with activation of EGFR leading to upregulation of the postulated ER $\alpha / E R \beta / E G F R$ complex. This, in turn, leads to enhanced ER phosphorylation by EGFR as well as increased sensitivity to the effects of endogenous EGF, both of which induce cell survival and/or proliferative pathways. Consequently, elevated oxidative stress 


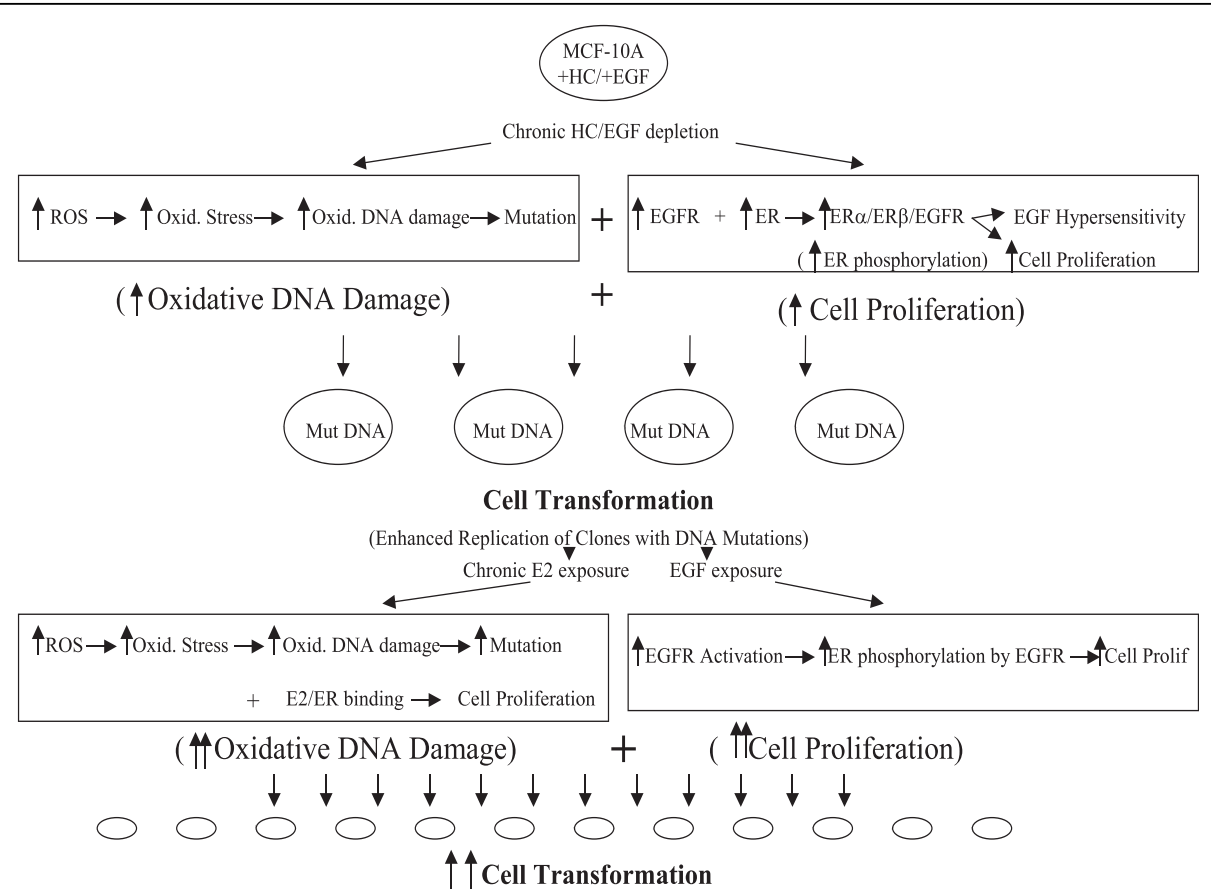

Figure 8 Proposed Model for the Transformation of Human Breast Epithelial Cells MCF-10A

concomitant with increased cell proliferation amplifies replication of clones carrying DNA mutations. Further chronic exposure of these initiated cells to E2 can again cause increased CE-mediated ROS generation and oxidative DNA damage-induced mutations. The prior upregulation of ER and ER phosphorylation also enhances E2/ ER binding leading to increased cell proliferation. Simultaneous exposure of initiated cells to EGF also augments EGFR activation and ER phosphorylation, again resulting in increased cell proliferation. More pronounced oxidative DNA damage and cell proliferation at this second stage, where exogenous E2 and EGF act, significantly raise cell transformation rates, once again due to the increased replication of clones with DNA mutations.

Part of the cellular machinery enabling such transformation is suggested by the unique cellular interconnections we observed within cultures grown in media conducive to transformation (Figs. 5 \&6). While the exact function of these interconnections is unknown, it is possible that they facilitate the channeling and/or sharing of nutrients, growth factors, etc., needed for foci survival. The discovery of the de novo creation of actinbased tunneling nanotubules (TNTs) which arise due to medium deprivation and are capable of transporting organelles between cells in different cells [75] provides support for this type intercellular communication.

This study demonstrates that microenvironmental manipulations, namely the simultaneous depletion of $\mathrm{HC}$ and EGF from culture medium, which increase intracellular oxidative stress, can induce transformation in the MCF-10A cell line. We have developed a growth protocol in which the effect of chronic, physiologically relevant microenvironmental alterations on cellular transformation can be examined. Each analysis of duplicate or triplicate samples from single experiments presented in this study represents the culmination of extensive prior work in the selection of optimal culture and treatment conditions. Exposure of cells to chronic, physiologic doses of E2 were required to effect transformation, conditions that mimic the lifetime exposure of the human breast to endogenous estrogens which is believed to play a part in the onset of breast cancer $[76,77]$. Both E2-mediated oxidative effects and ERmediated events were found necessary to effect transformation. Our work provides the first indications suggesting a direct association of EGFR and ER $\alpha$ as well as a possible ternary association (ER $\alpha / E R \beta / E G F R)$, which is highly induced in chronically HC/EGF-depleted MCF$10 \mathrm{~A}$ cells which are the most prone to transformation. Overall, results indicate that the immediate microenvironment of cells exerts powerful growth cues which ultimately determine their transformation potential.

\section{Acknowledgements}

This study was supported in part by grants from National Cancer Institute (CA37858), National Institute on Aging (AG14587), and Environmental Health Sciences (ES00260). The Authors are particularly grateful to Dr. Joachim Liehr's laboratory for providing 2-FI-E2. We dedicate this paper to Dr. 
Joachim Liehr, whose prior work helped steer the thinking and experimental design for the present study.

\section{Author details}

${ }^{1}$ School of Environmental Science and Management, Independent University, Bangladesh, House \#27, Road \#12, Baridhara, Dhaka-1212, Bangladesh. ${ }^{2}$ Department of Environmental Medicine, NYU School of Medicine, PHL Room 802, 550 First Avenue, New York, NY 10016, USA

\section{Authors' contributions}

RY conceptualized the study, designed and carried out all experiments, analyzed the data, carried out the statistical analyses, and drafted the manuscript. KF provided substantial intellectual input into the conceptualization and design of the study, interpretation of the data, and revision of the manuscript for final submission. All authors have read and approved the final manuscript.

\section{Competing interests}

The authors declare that they have no competing interests.

Received: 9 April 2010 Accepted: 1 September 2010

Published: 1 September 2010

\section{References}

1. Gullick JW, Bianco C, Normanno N, Martinez-Lacacia I, De Santis M, Ebert AD, Salomon DS: Growth factors and their receptors: a novel approach to the endocrinology of human breast cancer. Women and Cancer 1998, 1:29-57.

2. Ohshima $H$, Bartsche $H$ : Chronic infections and inflammatory processes as cancer risk factors: possible role of nitric oxide in carcinogenesis. Mutation Res 1994, 305:253-256.

3. Li Y, Trush MA, Yager JD: DNA damage caused by reactive oxygen species originating from a copper-dependent oxidation of the 2-hydroxy catechol of estradiol. Carcinogenesis 1994, 15:1421-1427.

4. Yager JD: Endogenous estrogens as carcinogens through metabolic activation. I Natl Cancer Inst 2000, 27:67-73.

5. Hayashi N, Hasegawa K, Komine A, Tanaka Y, McLachlan JA, Barrett JC, Tsutsui T: Estrogen-induced cell transformation and DNA adduct formation in cultured Syrian hamster embryo cells. Mol Carcinogenesis 1996, 16:149-156.

6. Bolton JL, Thatcher GRJ: Potential mechanisms of estrogen quinone carcinogenesis. Chem Res Toxicol 2008, 21(1):93-101.

7. Hamada J, Nakata D, Nakae D, Kobayashi Y, Akai H, Konishi Y, Okada F, Shibata T, Hosokawa M, Moriuchi T: Increased oxidative DNA damage in mammary tumor cells by continuous epidermal growth factor stimulation. J Natl Cancer Inst 2001, 93:214-219.

8. Arnold RS, Shi J, Murad E, Whalen AM, Sun CQ, Polavarapu R, Parthasarathy S, Petros JA, Lambeth JD: Hydrogen peroxide mediates the cell growth and transformation caused by the mitogenic oxidase Nox1. Proc Natl Acad Sci 2001, 98:5550-5555.

9. Fishman J, Osborne MP, Telang NT: The role of estrogen in mammary carcinogenesis. Ann NY Acad Sci 1995, 768:91-100.

10. Dickson RB, Stancel GM: Estrogen receptor-mediated processes in normal and cancer cells. J Natl Cancer Inst 2000, 27:135-145,

11. Tsutsui T, Barrett CJ: Neoplastic transformation of cultured mammalian cells by estrogens and estrogen-like chemicals. Environ Health Perspect Suppl 1997, 105:619-624.

12. Normanno N, Ciardiello F: EGF-related peptides in the pathophysiology of the mammary gland. J. Mammary Gland Biol. Neoplasia 1997, 2:143-151.

13. Cormier EM, Wolf MF, Jordan VC: Decrease in estradiol-stimulated progesterone receptor production in MCF-7 cells by epidermal growth factor and possible clinical implication for paracrine-regulated breast cancer growth. Cancer Res 1989, 49(3):576-580.

14. Stoica A, Saceda M, Doraiswamy VL, Coleman C: Regulation of estrogen receptor- $\alpha$ gene expression by epidermal growth factor. $J$ Endocrinol 2000, 165(2):371-378.

15. Clemons M, Goss P: Estrogen and the risk of breast cancer. N Engl J Med 2001, 344:276-285

16. Fuqua SAW, Russo J, Shackney SE, Stearns ME: Estrogen, estrogen receptors and selective estrogen receptor modulators in human breast cancer. Women and Cancer 2000, 2:21-32.
17. Khan SA, Sachdeva A, Naim S, Meguid MM, Marx W, Simon H, Halverson JD, Numann PJ: The normal breast epithelium of women with breast cancer displays an aberrant response to estradiol. Cancer Epidemiol. Biomarkers \& Prev 1999, 8:867-872

18. Shoker BS, Jarvis C, Clarke RB, Anderson E, Hewlett J, Davies MPA, Sibson DR, Sloane JP: Estrogen receptor-positive proliferating cells in the normal and pre-cancerous breast. Amer J Pathol 1999, 155:1811-1815.

19. Cavalieri $E$, Rogan $E$ : The unifying mechanism in the initiation and prevention of breast and other cancers. BMC Proceedings 2009, 3(Suppl 5):S8.

20. Russo J, Russo $\mathrm{HH}$ : The role of estrogen in the initiation of breast cancer. $J$ Steroid Biochem Mol Biol 2006, 102:89-96.

21. Russo $\mathrm{H}_{\text {, Russo }}$ : Role of hormones in mammary cancer initiation and progression. J Mammary Gland Biol Neoplasia 1998, 3:49-61.

22. Cavalieri E, Chakravarti D, Guttenplan J, Hart E, Ingle J, Jankowiak R, Muti P, Rogan E, Russo J, Santen R, Sutter T: Catechol estrogen quinones as initiators of breast and other human cancers: Implications for biomarkers of susceptibility and cancer prevention. Biochim Biophys Acta 2006, 1766:63-78.

23. Fernandez SV, Russo $\mathrm{H}$, Russo J: Estradiol and its metabolites 4hydroxyestradiol and 2-hydroxyestradiol induce mutations in human breast epithelial cells. Int J Cancer 2006, 118:1862-1868.

24. Mense SM, Remotti F, Bhan A, Singh B, El-Tamer M, Hei TK, Bhat H: Estrogen-induced breast cancer: alterations in breast morphology and oxidative stress as a function of estrogen exposure. Toxicol Appl Pharmacol 2008, 232(1):78-85.

25. Liehr JG: 2-Fluoroestradiol, separation of estrogenicity from carcinogenicity. Mol Pharmacol 1983, 23(2):278-281.

26. Liehr JG, Stancel GM, Chorich LP, Bousfield GR, Ulubelen AA: Hormonal carcinogenesis: separation of estrogenicity from carcinogenicity. Chem Biol Interact 1986, 59(2):173-184.

27. Liehr JG: Dual role of oestrogens as hormones and pro-carcinogens: tumour initiation by metabolic activation of oestrogens. Eur J Cancer Prev 1997, 6:3-10.

28. Han X, Liehr JG: 8-hydroxylation of guanine bases in kidney and liver DNA of hamsters treated with estradiol: role of free radicals in estrogeninduced carcinogenesis. Cancer Res 1994, 54:5515-5517.

29. Liehr JG, Ricci MJ: 4-Hydroxylation of estrogens as marker of human mammary tumors. Proc Natl Acad Sci 1996, 93:3294-3296.

30. Musarrat J, Arezina-Wilson J, Wani AA: Prognostic and aetiological relevance of 8-hydroxyguanosine in human breast carcinogenesis. Eur $J$ Cancer 1996, 32A:1209-1214.

31. Anderson D, Schmid TE, Baumgartner A, Cemeli-Carratala E, Brinkworth $M H_{\text {, }}$ Wood JM: Oestrogenic compounds and oxidative stress (in human sperm and lymphocytes in the Comet assay). Mutat Res 2003, 544:173-178.

32. Berthois $Y$, Katzenellenbogen JA, Katzenellenbogen BS: Phenol red in tissue culture media is a weak estrogen: implications concerning the study of estrogen-responsive cells in culture. Proc Natl Acad Sci USA 1986, 83(8):2496-2500

33. Rajendran KG, Lopez T, Parikh I: Estrogenic effect of phenol red in MCF-7 cells is achieved through activation of estrogen receptor by interacting with a site distinct from the steroid binding site. Biochem Biophys Res Commun 1987, 142(3):724-731.

34. Grenman SE, Van Dyke DL, Worsham MJ, England B, McClatchey KD, Hopkins M, Babu VR, Grenman R, Carey TE: Phenotypic characterization, karyotype analysis and in vitro tamoxifen sensitivity of new ER-negative vulvar carcinoma cell lines, UM-SCV-1A and UM-SCV-1B. Int J Cancer 1990, 45(5):920-927.

35. El-Zarruk AA, van den Berg HW: The antiproliferative effects of tyrosine kinase inhibitors towards tamoxifen-sensitive and tamoxifen-resistant human breast cancer cell lines in relation to the expression of epidermal growth factor receptors (EGF-R) and the inhibition of EGF-R tyrosine kinase. Cancer Lett 1999, 142:185-193.

36. Armelin MCS, Stocco RC, Armelin HA: Control of rat $\mathrm{C}_{6}$ glioma cell proliferation: uncoupling of the inhibitory effects of hydrocortisone hormone in suspension and monolayer cultures. J Cell Biol 2004, 97:455-458.

37. Valentini SR, Oliveira ML, Sasahara RM, Armelin MC: Glucocorticoidregulated gene in transformed to normal phenotypic reversion. Braz J Med Biol Res 1994, 27(2):541-546. 
38. Stanulis-Praeger BM, Jacobus $\mathrm{CH}$, Nuttall AE: Hydrocortisone modulates RA-induced growth inhibition of normal and transformed human embryonic lung fibroblasts. Nutr Cancer 1986, 8(3):171-184.

39. Dandona P, Thusu K, Hafeez R, Abdel-Rahman E, Chaudhuri A: Effect of hydrocortisone on oxygen free radical generation by mononuclear cells. Metabolism 1998, 47(7):788-791.

40. Marumo T, Schini-Kerth VB, Brandes RP, Busse R: Glucocorticoids inhibit superoxide anion production and p22 phox mRNA expression in human aortic smooth muscle cells. Hypertension 1998, 32:1083-1088.

41. Dandona P, Aljada A, Ghanim H, Mohanty P, Hamouda W, Al-Haddad W: Acute suppressive effect of hydrocortisone on $\mathrm{p} 47^{\text {phox }}$ subunit of nicotinamide adenine dinucleotide phosphate oxidase. Metabolism 2001, 50(5):548-552.

42. Okada Y, Okada M: Effect of a radical scavenger "water soluble protein" from broad beans (Vicia faba) on antioxidant enzyme activity in cellular aging. J Nutr Sci Vitaminol (Tokyo) 2000, 46(1):1-16.

43. Lieberthal W, Triaca V, Koh JS, Pagano PJ, Levine JS: Role of superoxide in apoptosis induced by growth factor withdrawal. Am J Physiol 1998, 275(Renal Physiol 44):F691-F702.

44. Briand P, Nielsen KV, Madsen MW, Petersen OW: Trisomy 7p and malignant transformation of human breast epithelial cells following epidermal growth factor withdrawal. Cancer Res 1996, 56:2039-2044.

45. Briand P, Lykkesfeldt AE: An in vitro model of human breast carcinogenesis: epigenetic aspects. Breast Cancer Res Treat 2001, 65:179-187.

46. Manni A, Wechter R, Verderame MF, Mauger D: Cooperativity between the polyamine pathway and HER-2neu in transformation of human mammary epithelial cells in culture: role of the MAPK pathway. Int J Cancer 1998, 76:563-570.

47. Russo J, Calaf G, Sohi N, Tahin Q, Zhang PL, Alvarado ME, Estrada S, Russo $1 \mathrm{H}$ : Critical steps in breast carcinogenesis. Ann New York Acad Sci 1993, 698:1-20.

48. Mangold KA, Hubchak S, Mangino MM, Laconi S, Scarpelli DG: In vitro carcinogenesis of hamster pancreatic duct cells: cellular and molecular alterations. Carcinogenesis 1994, 15(9):1979-1984.

49. Burdick AD, Davis II JW, Liu KJ, Hudson LG, Shi H, Monske ML, Burchiel SW: Benzo(a)pyrene quinones increase cell proliferation, generate reactive oxygen species, and transactivate the epidermal growth factor receptor in breast epithelial cells. Cancer Res 2003, 63:7825-7833.

50. Stalford AC, Maggs JL, Gilchrist TL, Park BK: Catecholestrogens as mediators of carcinogenesis: correlation of aromatic hydroxylation of estradiol and its fluorinated analogs with tumor induction in Syrian hamsters. Mol Pharmacol 1994, 45(6):1259-1267.

51. Cavalieri E, Frenkel K, Liehr JG, Rogan E, Roy D: Estrogens as endogenous genotoxic agents-DNA adducts and mutations. J Natl Cancer Inst 2000, 27:75-93.

52. Tritscher AM, Seacat AM, Yager JD, Groopman JD, Miller BD, Bell D, Sutter TR, Lucier GW: Increased oxidative DNA damage in livers of 2,3,7,8tetrachlorodibenzo-p-dioxin treated intact but not ovariectomized rats. Cancer Lett 1996, 98:219-225.

53. Dong XF, Berthois Y, Martin PM: Effect of epidermal growth factor on the proliferation of human epithelial cancer cell lines: correlation with the level of occupied EGF receptor. Anticancer Res 1991, 11(2):737-743.

54. Vorherr H: Pregnancy and lactation in relation to breast cancer risk. Semin Perinatol 1979, 3(3):299-311.

55. Lipsett MB: Hormones, medication, and cancer. Cancer 1983, 51(12 Suppl):2426-2429.

56. Erwin RA, Kirken RA, Malabarba MG, Farrar WL, Rui H: Prolactin activates Ras via signaling proteins SHC, growth factor receptor bound 2, and son of sevenless. Endocrinology 1995, 136(8):3512-3518,.

57. Arendt LM, Grafwallner-Huseth TL, Schuler LA: Prolactin-growth factor crosstalk reduces mammary estrogen responsiveness despite elevated ER $\alpha$ expression. Am J Pathol 2009, 174(3):1065-1074.

58. Lydon JP, Ge G, Kittrell FS, Medina D, O'Malley BW: Murine mammary gland carcinogenesis is critically dependent on progesterone receptor function. Cancer Res 1999, 59(17):4276-4284.

59. Anderson $\mathrm{E}$ : The role of oestrogen and progesterone receptors in human mammary development and tumorigenesis. Breast Cancer Res 2002, 4:197-201.
60. Kurebayashi J, Otsuki T, Moriya T, Sonoo H: Hypoxia reduces responsiveness of human breast cancer cells. Jpn J Cancer Res 2001, 92(10):1093-1101.

61. Tamir S, Izrael S, Vaya J: The effect of oxidative stress on ER $\alpha$ and ER $\beta$ expression. J Steroid Biochem Mol Biol 2002, 81:327-332.

62. Ohnishi A, Oda Y, Hayakawa Y: Characterization of receptors of insect cytokine, growth-blocking peptide, in human keratinocyte and insect Sf9 cells. J Biol Chem 2001, 276(41):37974-37979.

63. Pietras RJ: Interactions between estrogen and growth factor receptors in human breast cancers and the tumor-associated vasculature. Breast $J$ 2003, 9(5):361-373.

64. Marquez DC, Lee J, Lin T, Pietras RJ: Epidermal growth factor receptor and tyrosine phosphorylation of estrogen receptor. Endocrine 2001, 16(2):73-81.

65. Banerjee S, Sengupta K, Saxena NK, Dhar K, Banerjee SK: Epidermal growth factor induces WISP-2/CCN5 expression in estrogen receptor- $\alpha$ positive breast tumor cells through multiple molecular cross-talks. Mol Cancer Res 2005, 3(3):151-162.

66. Pietras R, Marquez DC, Chen H, Tsai E, Weinberg O, Fishbein M: Estrogen and growth factor receptor interactions in human breast and non-small cell lung cancer cells. Steroids 2005, 70:372-381.

67. Zhu Y, Sullivan LL, Nair SS, Williams CC, Pandey AK, Marrero L, Vadlamudi RK, Jones FE: Coregulation of estrogen receptor by ERBB4/ HER4 establishes a growth-promoting autocrine signal in breast tumor cells. Cancer Res 2006, 66(16):7991-7998.

68. Boerner JL, Gibson MA, Fox EM, Posner ED, Parsons SJ, Silva CM, Shupnik MA: Estrogen negatively regulates epidermal growth factor (EGF)-mediated signal transducer and activator of transcription 5 signaling in human EGF family receptor-overexpressing breast cancer cells. Mol Endocrinol 2005, 19(11):2660-2670.

69. Levin ER: Bidirectional signaling between the estrogen receptor and the epidermal growth factor receptor. Mol Endocrinol 2003, 17(3):309-317.

70. Razandi M, Pedram A, Park ST, Levin ER: Proximal events in signaling by plasma membrane estrogen receptors. J Biol Chem 2003, 278(4):2701-2712.

71. Filardo EJ: Epidermal growth factor receptor (EGFR) transactivation by estrogen via the G-protein-coupled receptor, GPR30: a novel signaling pathway with potential significance for breast cancer. J Steroid Biochem Mol Biol 2002, 80:231-238.

72. Lichtner RB: Estrogen/EGF receptor interactions in breast cancer: rationale for new therapeutic combination strategies. Biomed Pharmacother 2003, 57:447-451.

73. Hiraku Y, Yamashita N, Nishiguchi M, Kawanishi S: Catechol estrogens induce oxidative DNA damage and estradiol enhances proliferation. Int $J$ Cancer 2001, 92:333-337.

74. Russo J, Lareef MH, Balogh G, Guo S, Russo IH: Estrogen and its metabolites are carcinogenic agents in human breast epithelial cells. J Steroid Biochem Mol Biol 2003, 87:1-25,.

75. Rustom A, Saffrich R, Markovic I, Walther P, Gerdes H: Nanotubular highways for intercellular organelle transport. Science 2004, 303:1007-1010.

76. Lippman ME, Krueger KA, Eckert S, Sashegyi A, Walls EL, Jamal S, Cauley JA, Cummings SR: Indicators of lifetime estrogen exposure: effect on breast cancer incidence and interaction with raloxifene therapy in the multiple outcomes of raloxifene evaluation study participants. J Clin Oncol 2001, 19(12):3111-3116.

77. Clamp A, Danson S, Clemons M: Hormonal risk factors for breast cancer: identification, chemoprevention, and other intervention strategies. Lancet Oncol 2002, 3(10):611-619.

\section{doi:10.1186/1475-2867-10-30}

Cite this article as: Yusuf and Frenkel: Morphologic transformation of human breast epithelial cells MCF-10A: dependence on an oxidative microenvironment and estrogen/epidermal growth factor receptors. Cancer Cell International 2010 10:30. 